\title{
Development Geography at the Crossroads of Livelihood and Globalisation
}

\author{
LEO DE HAAN* \& ANNELIES ZOOMERS** \\ * Centre for International Development Issues Nijmegen, University of Nijmegen, PO \\ Box 9104, 6500 HE Nijmegen, The Netherlands.Email: L.deHaan@maw.kun.nl \\ ** Centre for Research and Documentation on Latin America, Keizersgracht 395-397 \\ 1016 WW Amsterdam, The Netherlands.Email: zoomers@cedla.uva.nl
}

Received: July 2002; revised February 2003

\section{Abstract}

This article explores new insights generated by livelihood research with respect to poverty problems in the world and how people deal with global challenges. Through the examination of the changing outlines of livelihood in the present era of globalisation, we unravel the fuzzy relation between globalisation and local development from an actor point of view. First, the article analyses the historical and theoretical context in which the modern livelihood approach developed, followed by a short explanation of its contemporary definition. Then, globalisation trends in livelihoods are considered in order to determine the consequences for local development. The main issues reviewed are: the decomposition of households; the increased diversification of livelihoods; and the emergence of multi-local livelihoods and livelihood networks. In the conclusion it is argued that the future agenda on local development in development geography should include the study of rooted and dispersed livelihoods.

\section{Key words}

livelihood, globalisation, diversification, local development, household fragmentation, social networks 


\section{INTRODUCTION}

In an attempt to better understand inequalities in the world, development geographers have increasingly adopted a livelihood perspective in the analysis of poverty. Since the 1990s, this perspective has gained momentum as a way of looking at development by putting people at the centre, stressing their active role in exploring opportunities and coping with change. Poor people are at the focal point of livelihood studies. But as opposed to earlier approaches to poverty that tended to portray people as victims of structural constraints and focused on the material aspects of life from the perspective of specific, locally bound man-land interactions, the modern approach recognises that livelihood is multi-dimensional, covering not only economic, but also political, cultural, social and ecological aspects. Moreover, today's livelihoods are based on a range of assets, income opportunities, and product and labour markets which are located in different places and interact in turn with other places, meaning that livelihoods both depend on and shape global forces. This article examines the changing outlines of livelihood in the present era of globalisation. In this way it tries to unravel the fuzzy relation between globalisation and local development from an actor point of view.

First, the historical and theoretical context in which the modern livelihood approach developed is analysed followed by a short explanation of its contemporary definition. As to the latter, two trends are identified. The first concerns an increased emphasis on its 
holistic features and the second the surmounting of its micro-orientation. Both trends improve the concept's ability to tackle issues of local development in globalisation. Next, the most pressing issues are reviewed. Livelihood research has yielded a large number of case studies on the particularities and diversity of livelihoods. The ensuing discussion identifies globalisation trends in livelihoods in order to determine the consequences for local development. The first concerns the decomposition of households. A trend is identified towards increasingly individualised livelihoods and the erosion of communal solidarity. The importance of this is highlighted in its translation into increased diversification of livelihoods under globalisation. We will show that the rise in livelihood opportunities runs parallel to the decomposition of households. The third concerns the emergence of multi-local livelihoods and territorial livelihood networks. This trend more or less constitutes the spatial dimension of the two other trends. In the conclusion, the preceding discussion results in the argument that future research agenda on local development in development geography include the study of rooted and dispersed livelihoods.

\section{THE LIVELIHOOD APPROACH: ITS GEOGRAPHICAL ROOTS AND CONTEMPORARY MEANING}

For a long time, geographers in their analyses of local development focused on environmental and spatial features of life, portraying people as mere victims of structural constraints. When geography became recognised as an academic discipline in the 19th 
century, much attention was paid to the landscape and often there was a strong belief in the moulding power of the physical environment on human activities. This interest in the physical features of the landscape lasted a long time, even though increasing attention was paid to human agency, and the capacity of man to choose between a range of possible responses to physical conditions. De Haan (2000a, p. 346) identified the notion of genre de vie in early $20^{\text {th }}$-century French geography as the first conception of livelihood in modern geography. Vidal de la Blache introduced genre de vie explaining that within a specific geographical setting there is a "highly localised, rooted, stable and socially bounded connection between people and the land" called the pays (Johnston et al. 2000, p. 294).

After World War II livelihood as a concept almost completely vanished in development geography due to the dominant structural perspectives of dependencia and neo-Marxist approaches. Once these lost appeal a much more actor-oriented post-Marxist approach emerged in development geography. While it continued to put emphasis on inequalities in the distribution of assets and power it acknowledged that people make their own history, though not independently of structural imperatives. Moreover, it drew insights from other approaches such as feminism, for example with respect to power relations (Johnston 1993, p. 233-234). Post-Marxist development geography gave preference to a focus on local development as "the world of lived experience, the micro-world of family, network and community” (Johnston 1993, p. 229). Thus, in development geography attention increasingly turned to issues of poverty, vulnerability and marginalisation at "the geographical scale of experience”, as Taylor (1982) called it. 
It is from this position that the revitalisation of the livelihood approach in development geography started. Its orientation on actors and agency and its view on local development is best explained by Johnston (1993, p. 236-245) who showed that Giddens' (1984) structuration theory gave way to a view of the locale. This provides on the one hand the setting of human interaction and on the other hand is the subject of transformation by this interaction. According to Giddens, a particular locale provides resources and knowledge on which actors can base their action and at the same time it constrains human actions because it binds them to the resources and knowledge provided. The concept of locale became known as locality in British geography: the everyday working and living space of actors. Johnston (1993, p. 243) summarised it as follows: the structuration of social relations in daily life contains many similarities but leads to different outcomes in different places, recognising the uniqueness of the place without denying causation and general operative processes. Focusing on place prevents the structure-agency view of becoming either voluntaristic or deterministic: everyday life provides both the context for people's actions and is re-created by those actions. Local differences are reflections of cultural variations, which refute economic determinism. However, local differences do not challenge the existence of general operative processes. This constitutes the broader theoretical background in which the contemporary livelihood approach developed and it also clarifies its understanding of contemporary globalisation. Generally livelihood studies understand globalisation as the interaction between global forces and unbounded world wide flows on the one hand and local contexts on the other hand, i.e. the globallocal nexus or glocalisation (Robertson 1995). We will show that livelihood research 
although at first sometimes micro and locally biased is increasingly interested both in this global dimension and in local development as its localised mediation.

From the 1990s livelihood studies increasingly stressed that (poor) people should not be described as passive victims: even though decisions are often made within the confines of limiting structural conditions, households have a "veneer of free choice" (Humphries 1982). People have an active role in inducing change, being able to adapt or respond to changing circumstances. Already in the early 1980s, Schmink (1984, p. 88) stressed the importance of "highlighting the active, resourceful role played by (poor) people in providing for their own sustenance despite their lack of access to services and to an adequate income”. In contemporary livelihood studies "people manage an array of resources or assets (....) within a dynamic context in which assets and decision-making interact: a livelihood system is a dynamic realm that integrates both the opportunities and assets available to a group of people for achieving their goals and aspirations, as well as interactions with and exposure to a range of beneficial or harmful ecological, social, economic and political perturbations that may help or hinder a group's capacities to make a living” (Hoon et al 1997, p. 5). Livelihood is seen as a highly complex, allencompassing concept, which is not restricted to the ecological or to the economic or productive aspects of life. The most quoted definition of livelihood is that given by Carney (1998, based on Chambers and Conway 1992, p. 7): "a livelihood comprises the capabilities, assets (including both material and social resources) and activities required for a means of living. A livelihood is sustainable when it can cope with and recover from stresses and shocks and maintain or enhance its capabilities and assets both now and in 
the future, while not undermining the natural resource base”. According to Long (1997) livelihood "best expresses the idea of individuals and groups striving to make a living, attempting to meet their various consumption and economic necessities, coping with uncertainties, responding to new opportunities, and choosing between different value positions". Or, as Wallman (1984; in Appendini 2001, p. 25) puts it: "livelihood is never just a matter of finding or making shelter, transacting money, getting food to put on the family table or to exchange on the market place. It is equally a matter of ownership and circulation of information, the management of skills and relationships and the affirmation of personal significance .... and group identity. The tasks of meeting obligations, of security, identity and status, and organising time are crucial to livelihood as bread and shelter”. The holistic nature of livelihood is also stressed by Bebbington (1999, p. 2022) who in the following statement describes it as a combination of produced, human, natural, social and cultural assets. "A livelihood encompasses income, both cash and in kind, as well as the social institutions (kin, family, village), gender relations, and property rights required to support and to sustain a given standard of living. A livelihood also includes access to and the benefits derived from social and public services provided by the state such as education, health services, roads, water supplies and so on”. Bebbington shows that sufficient consideration needs to be afforded to the various dimensions of livelihood. "A person's assets, such as land, are not merely means with which he or she makes a living: they also give meaning to that person's world. Assets are not simply resources that people use in building livelihoods: they are assets that give them the capability to be and to act. Assets should not be understood only as 'things' that allow survival, adaptation and poverty alleviation. They are also the basis of an agent's power 
to act and to reproduce, challenge or change the rules that govern the control, use and transformation of resources” (Giddens; in Bebbington 1999, p. 2022).

Summarising we can establish that the modern conception of livelihood in development geography is less focused on man-land relations as compared to its roots in classical French geography. Nevertheless, a large number of authors - usually those who follow the above-mentioned definition proposed by Carney (1998) and who often speak about 'sustainable livelihoods' - still pay specific attention to these man-land relations. However, the trend is clearly towards a broadening of the scope in order to include nonenvironmental and non-economic aspects. We believe that this holistic view on livelihood is an improvement because it makes the conceptualisation more realistic. But there is indeed the danger that the concept becomes a 'container' for "everything that goes on in human life" and thus will loose its analytical value. A second trend that must be indicated concerns the level of scale. Livelihood studies are still characterised by a microorientation, that is by a focus on household members, households, families, or at best, local communities. However, at the same time extra-local and meso or macro contextual relations have been included in the analysis. We consider both trends as clear signs of the increasing maturity of the concept, because they increase the applicability of the concept to analyse issues of local development in globalisation. In the next section we will review the most pressing of these issues.

\section{LIVELIHOOD DYNAMICS IN THE ERA OF GLOBALISATION}


Up to now, livelihood research has resulted in the publication of large numbers of case studies, bringing to the fore the particularities and diversity of livelihood situations and practices. The authors stress the diversity of poverty situations and the multidimensionality of livelihood, but make less effort to aggregate and generalise their findings. The following is an attempt to analyse the trends during the last ten years, with an emphasis on "livelihoods in globalisation" and the implications for local development.

With respect to globalisation we refrain from resorting to the usual stereotypes such as financial flash capital driving up or pushing down share prices, world wide competition between firms, uniformity of consumer goods, information spreading instantaneously to all parts of the globe through television, mobile phones, internet and email. Instead, we define globalisation in the same vein as De Ruijter (1997, p. 381-382) in terms of technological innovations in transport, automation and telecommunications resulting in massive exchanges of people, goods, services and ideas. Thus globalisation is no longer a process of internationalisation, but rather the characteristic of a system spanning the globe, meaning that each particular entity has to be understood within the framework of the world as a whole. De Haan (2000a, p. 354-357) contends that along with increased homogenisation of economy, society and culture, one is also inclined to recognise counter-forces leading to increased diversity, cultural fragmentation and regionalism. Reinvention of local traditions and identities is seen as an answer to the loss of identity through cultural homogenisation. This so-called "localisation" is not limited to the social and the cultural domain, but extends to the economic and the political domains too. The latter concerns the restructuring of the welfare state involving privatisation and deregulation, or even clear-cut disintegration. So, we understand globalisation as the 
interaction between global forces and flows on the one hand and local contexts on the other hand, i.e. what Robertson (1995) has referred to as "glocalisation".

\section{Social change: decomposition of households and erosion of community life}

By putting people on the centre stage, livelihood research has helped to open the black box of the household. Development geographers have traditionally given much attention to the household, which they considered as the most important unit of analysis. While considering it as "a single decision-making unit maximising its welfare subject to a range of income-earning opportunities and a set of resource constraints” (Ellis 1997, p. 12), households were usually defined as co-resident groups of persons, who share most aspects of consumption, drawing on and allocating a common pool of resources including labour, to ensure their material reproduction. The boundaries and functions of households were usually defined primarily in economic or material terms, and only secondarily in terms of cohesion, for example a set of social relations and mutual obligations defined by kinship or forms of reciprocity.

Yet, contemporary livelihood studies stress that, instead of being victims, people play active roles in shaping their livelihood. This focus on the active involvement of people in responding to and enforcing change also engendered an increasing awareness of diverging positions within the household. Rather than "harmonious" entities pursuing an optimal balance, individual household members pursue individual ways to improve their situation. From an awareness of intra-household relations now emanates the realisation that globalisation has impacted on the characteristics and functions of households. The old assumption of a nuclear or extended family - comprising a male breadwinner, his 
wife who may be non-working, dependent children, and other family members - needs to be revised, just as traditional patterns of labour division. Rather than pursuing an optimal balance in a harmonious domestic unit, individuals now pursue their own ways to improve their situation, for example by diversifying their livelihood or by moving to a new location in order to exploit new opportunities. In many cases, traditional solidaritybased principles of pooling incomes, consumption and labour force within households have weakened considerably. Thus, although individuals remain members of domestic units we call households, they are increasingly considered to act independently. Furthermore, following the already well-known disintegration of extended families is the disintegration of nuclear families. The single-person household is not limited to industrialised societies. Also, in many parts of the world, the number of female-headed households has increased. The elderly have increasingly become a separate and often isolated group, no longer cared for in extended families.

Along with the growing complexity of labour division, the interests of a household's individual members will not always be consistent with the family goal and vice versa. Variations in personal capacities and motivation affect the interrelationships among the various activities as well as the degree of internal cohesion. Conflict and competition may arise between activities and among members of the household. What benefits the individual needs not benefit the family and vice versa.

The following example from northern Togo illustrates our argument (De Haan 1993). Besides, it demonstrates that the trends established do not appear of the blue. Globalisation is a recent phenomenon in the sense that it should be regarded as a contemporary stage, perhaps even the tailpiece, of a historical process of 
internationalisation and growing interdependence that started with colonialism. Therefore, the changes in livelihood we observe often already have colonial roots. What is typically associated with globalisation are the scale and intensity of the identified change.

On the eve of colonialism northern Togo was an agricultural society organised along lines of kinship clans and lineage. Production was organised through the lineage and the power of its eldest based on spiritual relations with the ancestors and his control of the marital system. The eldest decided when it was time to offer one of the daughters of the lineage to another lineage in exchange for a bride for one of the young men. Marriage, and subsequently the birth of offspring, was the only way for a man to increase his social status. These rules gave the eldest in that society the authority over the labour of the young men of their lineage and consequently over the most important livelihood activity, i.e. agriculture. Of course, intra-lineage tensions would have occurred, but the point is that in the end the young had to adapt to the decisions of the old, as women had to comply with decisions taken by men. There simply was no alternative in this closed society.

In contrast, colonialism constituted an alternative by creating product and labour markets. French colonial administration levied personal taxes to be paid by every able-bodied, adult man. The natives earned money from the production of newly introduced groundnuts and sale to trading firms, which enabled them to pay the taxes. From the 1930s until after independence in 1960 gradually every man cleared land to grow groundnuts and later cotton. Sale of produce, as well as the allocation of labour and other 
inputs on these personal fields, fell beyond the authority of the lineage's eldest. Growing monetary incomes from commercial fields increased the independence of young men. From the 1970s the same trend with respect to women became apparent. They started to grow vegetables, rice and cassava for the market on small individual plots, next to their traditional home gardens. As a consequence, since the 1960s the lineage as a residential and production unit comprising some 50 people, from the lineage head to his younger brothers, wives and children gave way to the household consisting of about 12-15 people, i.e. a man, his wife/wives and their children. But already in the 1980s agricultural decision-making became a complicated process in these households. Millet and sorghum, the staple foods, were grown on communal household fields under the supervision of the head of the household. However, even in his organisation of inputs (mainly fertiliser) and labour for these grain fields, he had to consider his own personal fields and those of his wives and older sons. We do not even touch upon the issue of who was responsible which expenditure.

At present, northern Togo has only a modest (urban and rural off-farm) labour market. However, the emerging colonial labour market that offered a second alternative to traditional livelihood was situated in the cacao-producing export areas in southern Ghana. In the early days, these cacao areas formed a temporary or even permanent way to build up an independent livelihood outside of traditional society for thousands of young men from northern Togo. This position is now taken over by the main West African cities on the coast.

Now, due to the integration of entire households in northern Togo the solidarity-based residential and production units are no longer pooling incomes, consumption and labour. 
Even in nuclear households, members are increasingly acting independently. The singleperson household is hardly found in this rural region; it belongs more to the world of migrated men in the big coastal cities. However, as a reverse of this, the number of female-headed households has increased. Moreover, a few elderly people now live on their own in poverty, sometimes with a young grandchild as housekeeper and the elderly often depend on charity.

This case exemplifies our argument that a trend towards increasingly individualised livelihoods, or at least individual decision-making concerning livelihood opportunities, can be detected. Its consequences for local development will became clear in the following sub-sections. Moreover, the case shows that local contexts, in this particular instance cultural norms of authority and gender as well as the ecological potential for a particular kind of - dry-season - cash crops, give rise to a specific outcome in which both homogenisation and localisation can be identified.

Furthermore, we observe that the decomposition of households often has gone hand in hand with the erosion of community life. Village or community organisations no longer perform the traditional role of a safety valve, enabling households to benefit from the advantages of scale, the distribution and redistribution of communal resources, while minimising the negative external effects of individual behaviour. In many areas, traditional village organisations are losing their importance as illustrated by the following case from the Bolivian Andes (Zoomers 1999, p. 38-39).

The findings of the large-scale evaluative survey show that while the communal organisation remains important, its benefits should not be exaggerated. Most of its 
remaining influence is often related to ideological or cultural traditions, such as festivals and communication. An arena in which the communal organisation still plays an important role is in projects that are directly linked to economies of scale, where the demand for resources ........ exceeds the individual capacities of even the wealthiest members of the community.

In many villages, however, the communal organisation is steadily losing ground...... The data indicate a process of de-communalisation or de-collectivisation in the use of divisible resources such as land and livestock. Moreover, a communal project's ultimate success depends largely on its individual benefits, that is, households usually value their individual interests over communal interests. Communal plans receive support if they benefit individuals. However, given the population's heterogeneity, community efforts instigate conflicts and rivalry far more often than is suggested in the literature.

\section{Economic fragmentation: multi-tasking and income diversification}

Livelihood studies have ascertained that during the last decade, increasing numbers of people have opted for a development path characterised by multi-tasking and income diversification. There is a tendency towards livelihood diversification, viz. "a process by which ....households construct an increasingly diverse portfolio of activities and assets in order to survive and to improve their standard of living” (Ellis 2000, p.15). Today, few among the poor derive all their income from just one source, e.g. wage labour, or hold all their wealth in the form of just one single asset. 
In the 1970-1980s, processes of income diversification were usually described as proof of decampesinación, which would inevitably result in processes of marginalisation as a consequence of capitalist expansion. "The tendency that salaries and monetary incomes are insufficient to cover consumption needs forces households and individuals to resort to strategies to stretch and supplement the wage" (Deere et al., 1978). In livelihood studies, however, diversification is described more as a structural phenomenon, which exists in both urban and rural contexts. In many cases, the bulk of income of the rural poor no longer originates from agriculture, and it is no longer realistic to classify the population as small farmers or the landless poor. At the same time, among the urban poor, part of the population is now involved in urban agriculture, which provides additional food supply. Multiple motives prompt people to diversify their assets, incomes and activities. Multi-tasking is seen as a way to compensate for insufficient income or temporary crisis situations. It is a strategy to escape poverty, to cope with insecurity or to reduce risk. Ellis (2000) stresses that diversification is pervasive and enduring in the sense that the phenomenon occurs everywhere and does not seem to be transient. Diversification does not mean having an occasional earning besides a main activity: it means multiple income sources. Although many families derive their income from an ever-expanding range of different sources, usually this does not result in higher incomes. "It is the maintenance and continuous adaptation of a highly diverse portfolio of activities that is a distinguishing feature" of the poor (Ellis 2000, p. 4). Poverty induces households to intensify strategies for generating income, using available labour and resources as fully as possible. The poor tend to be the most engaged in complex, multi-activity income strategies. They adjust, cope, create and re-create their livelihoods under the impact of 
macro-economic circumstances, climatic variability and institutional change. "While both diversity and diversification may be taken overall to mean multiple and multiplying income sources, they are more invoked in the rural development context to imply diversification away from farming as the predominant or primary means of rural survival. Thus the expression 'highly diversified rural livelihoods' typically conveys the idea of livelihoods in which own account farming has become a relatively small proportion of the overall survival portfolios put together by farm families” (Ellis 2000, p. 14-15).

Even though livelihood research has contributed to a better understanding of how poor people maintain their lives by diversification, little is known about the mutual cohesion and interaction between their activities. The internal consistency of a portfolio of activities varies from case to case, and depends on seasonality, the division of labour and the availability of assets. Sometimes there is a facilitating relationship; that is, one activity is a necessary condition for the other. One example is the association between agriculture and animal husbandry through the exchange of feed, manure and animal traction. Other activities are much more complementary: they are related to each other by the principle of communicating vessels, for example combining agriculture with nonagrarian activities in order to compensate for declining returns from farming. In other cases, activities are mutually exclusive, or they compete: for example, migration might be incompatible with farming which requires a fixed time input.

Multi-tasking in the Andes is generally viewed as a method which allows farmers to derive optimal benefits from ecological heterogeneity. However closer analysis by Zoomers (1999, p. 27-28) reveals other factors: 
.....multi-tasking results from households' pursuit of several objectives at the same time. They need to provide food for themselves while trying to increase their cash income or prestige........ Most farmers in Chuquisaca and Potosi engage in multi-tasking, regardless of where they are located........ nearly all residents pursue a number of different activities at the same time. Aside from agriculture (animal husbandry and cultivation) and temporary migration (to various destinations), many farmers are involved in trade (selling agricultural crops, manure, wool, meat, milk and cheese, firewood and so forth), crafts (production of charcoal, ceramics, ironworks, weaving, bread baking, manufacturing agricultural devices etc) and wage labour (such as tailors, hairdressers and construction workers). Full specialisation is virtually absent within individual households.

In order to arrive at a conclusion, first and foremost it is important to note that apparently globalisation has boosted the range of livelihood opportunities even in remote corners of the globe and that especially the poor try out as many of those opportunities as possible. This does not necessarily mean that prosperity has increased, but it does mean that local development has become much more varied than ever before.

Second, it shows the significance of our observations about the decomposition of households, because the diversification trend runs parallel to the individualisation trend. Households partly diversify because individual members are able to decide in relative autonomy about the allocation of resources they have access to. No longer can the household head decide what will be done, nor is there always consultation about which income opportunities to explore or resources to allot at. The same holds true for the pooling of revenues. On the other hand, we do not argue that the household will become 
an insignificant feature in globalisation. Decision making at the household level still is a reality and, even more important, individual decision making is better understood against the background of the characteristics of the household people belong to. This also applies to migration which underlies our discussion in the next subsection.

Livelihood research has helped to show that human behavior should not always be seen as conscious, intentional or strategic: much of what people do cannot be classified as strategic. For example Devereux (2001), when discussing risk management, distinguishes between ex ante and ex post strategies. In his view ex ante strategies (e.g. planting lowrisk but low-return crops in dry areas) are forms of intentional behavior. However, he finds it more difficult to call ex post behavior strategic. "If people who are already malnourished cut their food consumption to one meal a day, as rural Africans routinely do during the annual soudure, in what sense are they coping?” (Devereux 2001, p.512). It is thus important to make a distinction between a household's strategy and its history. "Like the concept of adaptation, that of strategy can lose its meaning to the extent that it becomes a mere functionalist label applied ex post to whatever behavior is found" (Schmink 1984, p.95). De Bruijn and Van Dijk (forthcoming, p.11) prefer to speak about pathways rather than strategies: "A pathway is different from a strategy because a pathway need not to be a device to attain a pre-set goal which is set after a process of conscious and rational weighing of the actor's preferences. Rather it arises out of an iterative process in a step-by-step procedure in which goals, preferences, resources and means are constantly reassessed in view of new unstable conditions ...Individuals decide on the basis of a wide range of past experiences, rather than on a vision of the future, 
while these recollections of the past depend to a great extent on our intellectual concern in the present. Knowledge ... is gathered in an incremental learning process”. Here, past experience and learning are introduced as elements that blur the distinction between intentional and unintentional. Although the authors' emphasis is on individuals, rather than households as actors, they recognize structure too. Actors are taken to coordinate their actions with other actors. In this coordination process regularities arise, which prestructures subsequent decisions, like in Bourdieu's habitus (De Bruijn \& Van Dijk: forthcoming, p.12).

\section{Spatial dispersion: multi-local livelihoods and transnational networks}

In addition to multi-tasking, there is another trend in which poor people increasingly develop multi-local livelihoods (see also De Haan 2000a, p. 354). In development geography regions frequently have been conceived as demarcated areas and people as being rooted to localities. Concepts such as carrying capacity were applied to express the region's ability to support a certain population. But rapid urbanisation and the improvement of communications and transport technology have resulted in a significant increase of mobility. Increasing numbers now engage in urban and rural life, commuting from the countryside to the urban centres on a daily basis. Also, poor people supplement their income by travelling large distances to earn additional money as temporary migrants. Finally, there is a considerable group of transnational migrants. Especially in countries such as the Philippines, Morocco, Ghana, Lesotho, Bolivia, Ecuador and Paraguay, large groups are temporarily or semi-permanently living abroad, where they 
work as agricultural labourers or as legal and illegal housekeepers (Salman and Zoomers 2002).

Thus, persistent poverty under globalisation is reflected in the large numbers of rural and urban households which exploit opportunities in different places and therefore live from both agricultural and urban incomes. Old dichotomies such as urban-rural should therefore be reconsidered. Considerable numbers of people are no longer rooted in one place: although they maintain relations with their home community, they are also attached to other places. Especially the poorest households often do not organise their livelihood in one place, but function in larger networks. As a consequence, individuals are no longer organised as co-resident groups (i.e. concentrated in space) but resemble individual nodes, connected to each other by social networks, along which flow remittances, information and food. Thus, peoples' lives become increasingly interconnected via inter-local networks, at different spatial scales. The potential power of these networks, especially those created by transnational migration, is clearly demonstrated by De Haas (2001, p. 315-318) in his study of migration impacts on local development in the oases regions of Morocco.

In the Todgha valley migration has significantly contributed to improving many people’s standard of living. Many rural families have now moved from absolute poverty to being able to afford better nourishment and living conditions....... remittances can be considered as a safety net for underdeveloped rural areas, and can substantially contribute to alleviating poverty. The analysis has also demonstrated that current and returned international migrant households tend to invest more than do non-migrant and internal 
migrant households. ......(I)nternational migrant households do not generally spend excessive amounts of disposable income on conspicuous consumption ...... (M)igration should be perceived as a livelihood strategy that aims to spread income risk through diversifying the household's income sources. Migration should as be seen in the light of the general processes of income diversification and partial de-agrarisation and deruralisation of oasis livelihoods.... (M)igration can, in addition, be seen as a household strategy for overcoming local constraints on investments in the local economy...... In addition, through indirect multiplier effects, investments and consumption by migrants seem to have indirect positive effects on the economy of the valley. Investments by migrants create local income earning possibilities for many non-migrants.

Migration only seems a successful strategy for those families with relatives working abroad. Internal migrants often lead a difficult life, struggling to survive and leaving their families financially insecure. Their incomes .... are often unstable. Unlike the international migrant group, this group is seldom able to escape from poverty and (cannot) durably improve livelihoods by investing money in the local economy.

The analysis also pointed to the high spatial variability of migration impact. In the valleys, for example, local environmental conditions such as the availability of water and land clearly influence the intra-valley spatial allocation of agricultural investments........ Notwithstanding its positive impacts, there is also reason to believe that the development potential of migration is not being fully realised. ..........(E)xcessive bureaucracy and widespread corruption tend to complicate and slow down administrative procedures like, for example, obtaining business permits or title deeds on land and property......(M)ost 
inhabitants of the Todgha have a profound distrust of the central state and its local representatives.

Instead of defining their home in terms of boundedness, homogeneity and exclusion, people have to create new identities and find new social security mechanisms. Those who are living abroad are often inclined to cluster together in the same neighbourhood (see also Sassone 2002). Establishing and maintaining good relationships with others is of crucial importance for enhancing and maintaining a living (Kaag et al forthcoming). Local development can no longer be explained without taking into account the remittances sent by family members who have decided to migrate, and the flows of information connecting local space with the outside. On the other hand, a proper understanding of the livelihoods of migrants in their area of residence can only be achieved by taking into account their linkages with the home area. Actors do not behave or make decisions isolated from their social context, but nor do they adhere slavishly to a script written for them by the particular intersection of social categories they happen to occupy. Instead, their attempts and purposive action are embedded in a concrete ongoing system of social relations (Granovetter 1985, p. 487).

The concept of place, the uniqueness of particular places and place-based identities are hotly contested concepts in the contemporary context of increasing globalisation and the perceived threat of growing placelessness (Johnston et al., p. 582). Along with increased mobility, the individual's attachment to particular places, and the degree to which places link events, attitudes and other places (homogeneous place-based communities, or sites organised on the basis of social relations, meanings and collective 
memory), are less and less common. "The (post-)modern concept of place recognises the open and porous boundaries of places as well as the myriad interlinkages and interdependencies among places (Massey 1997, Perose 1993, Young 1990: In: Johnston et al. 2000, p. 583). Places can no longer be seen as a portion of geographical space and the romantic notion of place (stable, homogeneous place-based communities) is out of date.

\section{CONCLUSION: A RECONSTITUTED DEVELOPMENT GEOGRAPHY}

We have seen to what extent the livelihood approach has helped us to better understand local development by analysing how people have responded to global challenges. We have also seen that the livelihood perspective incorporates new insights into the issue of poverty. The livelihood approach is people-centred (i.e. centred on the actions and strategies of people), holistic (non-sectoral), and grounded in the multi-dimensionality of (daily) life. It acknowledges that poor people are important and imbued with agency, and that they actively shape their lives and thus local development, by means of their material and immaterial assets, notwithstanding the wider context.

The major trends illustrate that livelihood has become increasingly multi-local, multiple or multi-dimensional. The general picture of livelihood under globalisation is one of the "increased rearrangements of strategies using various capitals in different locations” (Kaag et al forthcoming, p.15). As a result of individualisation more and more households break up. Poor people nowadays are not only involved in multi-tasking, but 
are increasingly dispersed over multiple areas. These trends are often not in line with trends in policy making for local development, much of which is aimed at poor households, has a sectoral focus and concentrates on bounded intervention areas.

Globalisation is often depicted as a process contributing to a uniform world. It is clear though that the "capabilities, assets (including both material and social resources) and activities required for a means of living” (Carney 1999) are not equally distributed. Thus the ability of people to cope with (global) challenges, and thus the course of local development is also determined by geographical factors, viz. site and situation. Only people in resource-rich places (i.e. well connected to global space) are in a position to benefit, provided that they have access to those resources. This group will have opportunities to lead a stable and rooted life, and to specialise in the most remunerative activities, without migrating. However, the majority of the poor are located in the wrong place, that is in marginal and isolated areas that lack resources and infrastructure. The only way to benefit from global opportunities is to break up and diversify their economic activities, viz. to perform multi-tasking and to live in different places, thus pursuing multi-local livelihoods.

Nonetheless, our example of Moroccan migration networks showed that pursuing multi-local livelihood at one stage provides the very connection of the - peripheral locality to global space and its profitable livelihood opportunities at the next stage. At that time direct access to the network also provides a stable and rooted life to the ones that stayed behind. In a later stage local investments originating from the network even provide new livelihood opportunities to those without access to the migration network. For the majority of the poor, having a personal relationship with people at various 
locations has become a key element for their ability to cope with change, and establishing a secure livelihood, even if this means giving up their rooted life.

In one dimension local development concerns whether people will develop rooted or dispersed livelihoods. This is seen to depend on the availability of natural resources (land, water, forests, pastures, minerals) and infrastructure, and on market accessibility and the availability of social networks, which are of crucial importance for accessing information and resources from other areas. The success story of Machakos district in Kenya (Tiffin et al. 1994) clearly demonstrates our point.

The authors show that seriously eroded landscapes in the 1930s are turned into a prosperous countryside with terraces, trees, coffee and farmsteads in the 1990s while population was almost sixfold and acreages per capita had been more than halved.

Yields per acre have expanded by a factor of 6 and value of production (in constant prices) is now 10 times as high per acre and 3 times as high per capita.

The explanation for this success story starts with the forced construction of terraces in the colonial period and the introduction of ploughs by Kenyan soldiers returning from India in the Second World War. But the take-off in land conservation came after independence when forced labour disappeared, the construction of terraces was implemented by traditional working parties, and women started playing a leading role in the community, because of the migration of men to Nairobi. There is much organic fertilisation of crops livestock that used to be collectively herded are now held individually and in cowsheds fodder is grown and improved dairy breeds have been introduced. Extended families have increasingly given way to nuclear families and the position of women has been improved. 
The authors claim that the initiative for this metamorphosis came from the population itself which developed its livelihood on the basis of its own needs, perception, experience and knowledge, profiting from the revenues of labour migration and coffee exports. In addition, they used knowledge, training, support in soil and water conservation and new varieties provided by the government and donor agencies. The enabling role of the Kenyan government was especially acknowledged in the way that it facilitated the proper functioning of markets and land titling (De Haan 2000b, p. 362).

Machakos can be characterised as a relatively resource-poor region, although its rainfall regime is considerably more favourable than that of for example the Sahel. The interesting point is that the explanation of successful agricultural intensification is not only attributed to population pressure, but also to the learning experience of soldiermigrants in India, market integration (both the proximity of the Nairobi urban market and the boom in coffee prices in the 1970s and 1980s) and government policies.

At the moment, the livelihood approach focuses on the agency and the capacity of actors, but little attention is given to the structural and geographical constraints. Despite the active way people try to cope with opportunities, the majority of the poor are forced to lead dispersed and placeless lives, due to the lack of local opportunities. Multi-level rather than micro-level analysis is needed to gain an understanding of livelihood trends, "showing from a globalising perspective the connectivity of different levels of scale and putting social exclusion and poverty in front" (Baud et al. 2002). 
Development geographers should focus on making a conceptual update and on analysing how place and space influence the way people cope with global challenges, and vice versa. The old ideas about class and the assumed correlation with structural variables such as ownership of land are now perceived as something much more flexible and diffuse. People belonging to the same class in terms of consumption or property will show very diverse patterns of behaviour. Some aim at becoming or remaining full-time farmers, while others will prefer to leave the countryside and settle in metropolitan areas. Rather than categorizing people on the basis of access to land or ownership of cattle, local development is better understood by paying more attention to the way they respond and the variety of coping mechanisms they employ.

Globalisation may look like a new round with new opportunities for livelihood (De Haan 2000a, p. 357), but it is doubtful whether dispersed livelihoods will help people escape from poverty. An analysis of poor people’s day-to-day struggle to make a living even though the benefits of globalisation usually are described in such positive terms as adaptability, flexibility and mobility - shows that equilibrium and stability are more elusive than ever before.

\section{REFERENCES}


Appendini, K. (2001), Land and livelihood: what do we know, and what are the issues? In: A. ZoOmers, ed., Land and sustainable livelihood in Latin America, pp.23-38. Amsterdam: Royal Tropical Institute/Vervuert Verlag.

BAUD, I., J.POST, L. DE HAAN \& T. DIETZ, eds., (2002), Re-aligning government, civil society and the market. New challenges in urban and regional development. Essays in honour of G.A. de Bruijne. Amsterdam: Amsterdam Research Institute for Global Issues and Development Studies.

Bebbington, A. (1999), Capitals and capabilities: a framework for analysing peasant viability, rural livelihoods and poverty. World Development 27, 12, pp.2021-2044.

CARNEY, D., ed., (1998), Sustainable rural livelihoods. What contribution can we make? Department of International Development. Nottingham: Russell Press Ltd.

CHAMBERS, R. \& G. CONWAY (1992), Sustainable rural livelihoods: practical concepts for the $21^{\text {st }}$ century. Discussion Paper 296. Brighton: Institute of Development Studies, University of Sussex.

DE BRuin, M. \& H. VAN DiJK (forthcoming), Pathways and habitus: a framework for the analysis of decision making in high-risk environments (unpublished paper). Leiden: Africa Study Centre. 
DE HAAN, L, (1993), La Region des Savanes au Togo. L'Etat, les paysans et l'integration regionale 1885-1985. Paris: Karthala

DE HAAN, L. (2000a), Globalization, localization and sustainable livelihood. Sociologia Ruralis 40, 3, pp.339-365.

DE HAAN, L. (2000b), The question of development and environment in geography in the era of globalisation. GeoJournal, 50, pp.359-367

DE HAAS, H. (2001), Migration, Development and Agricultural Change in the SouthMoroccan Todgha Valley. The Arab World Geographer, 4, 4, pp. 302-320.

DE RuIJTER, A. (1997), The era of glocalisation In: Van Naerssen, T, M. Rutten and A. Zoomers eds, The Diversity of development. Essays in Honour of Jan Kleinpenning. Assen, Van Gorcum, , pp.381-388.

Deere, C., J. Humphries \& M. León de LeAl (1978), Class and historical analysis for the study of women and economic change. Paper presented at the Role of Women and Demographic Change Research Program. Geneva: International Labour Organization. 
DEVEREUX, S. (2001), Livelihood insecurity and social protection: a re-emerging issue in rural development. Development Policy Review 19, 4, pp.507-519.

ElLiS, F. (1998), Survey article: household strategies and rural livelihood diversification. The Journal of Development Studies, Vol.35, No.1, pp.1-38.

Ellis, F. (2000), Rural Livelihoods and Diversity in Developing Countries. Oxford: Oxford University Press.

GIDDENS, A. (1984), The constitution of society. An outline of the theory of structuration. Cambridge: Polity Press.

GranOvetTER, M. (1985), Economic action and social structure. The problem of embeddedness. Journal of Sociology, 91, 3, pp.481-510.

Hoon, P., N. Singh \& S. WANMALI (1997), Sustainable livelihoods: concepts, principles and approaches to indicator development. Paper presented at the workshop Sustainable Livelihood Indicators, Social Development and Poverty Eradication Division. New York: United Nations Development Program.

Humphries, J. (1982), The family and economy: notes towards a relative autonomy approach. Paper presented at the conference on demographic research 
in Latin America, Linking Individual, Household and Societal Variables. Ixtapan de la Sal: Social Sciences Research Council Mexico.

Johnston, R. (1993), Geography and geographers. Anglo-American human geography since 1945. $4^{\text {th }}$ edition. London: Edward Arnold.

Johnston, R., D. Gregory, G. Pratt \& M. Watts (2000), The dictionary of human geography. $4^{\text {th }}$ edition. Oxford: Oxford University Press.

KaAg, M., R. van Berkel, J. Brons, M. de Bruijn, H. van Dijk, L de HaAn, G. NoOteboom \& A. ZoOmers (2003). Poverty is Bad: Ways Forward in Livelihood Research. Paper presented at the CERES pathways project seminar. Utrecht: Interuniversitary Research School for Resource Studies for Development.

LONG, N. (1997) Agency and constraint, perceptions and practices. A theoretical position. In: H. de Haan \& N. Long, eds., Images and realities of rural life, pp.120. Assen: van Gorcum.

MASSEY, D. (1997) A global sense of place. In: T. BARNES \& D. GREgORY, eds., Reading human geography. The poetics and politics of inquiry, pp. 315-23. London: Edward Arnold. 
Penrose, J. ( 1993) Reification in the name. In: P. Jackson And J. Penrose, eds., Constructions of race, place and nation, pp. 27-49. London: UCL Press.

ROBERTSON R.(1995), Glocalisation: time-space and homogeneity-heterogeneity. In: M. Featherstone, S. Lash and R. Robertson eds, Global Modernities, pp.25-44. London: Sage.

SAlman, T. \& A. ZoOmers, eds., (2002), The Andean exodus: transnational migration from Bolivia, Ecuador and Peru. Cuadernos del Cedla 11, pp. 1-120. Amsterdam: Centre for Research and Documentation on Latin America.

SASsone, S. (2002) Espacios de vida y espacios vividos. El caso de los inmigrantes bolivianos en el área metropolitana de Buenos Aires. In: T. SALMAN \& A. ZoOMERS, eds., (2002) The Andean exodus: transnational migration from Bolivia, Ecuador and Peru. Cuadernos del Cedla 11, pp. 91-121. Amsterdam: Centre for Research and Documentation on Latin America.

ScHmink, M. (1984), Household economic strategies: review and research agenda. Latin American Research Review 19, 3, pp.87-101.

TAYLOR, P. (1982), A materialist framework for political geography. Transactions of the Institute of British Geographers, NS7, pp. 15-34 
Tiffin, M., M. Mortimore And F. Gichuki (1994), More People, Less Erosion. Environmental Recovery in Kenya. Chicester: Wiley

Wallmann, S. (1984), Eight London Households. London: Routledge.

Young, I.M. (1990), Justice and the politics of difference. Princeton: Princeton University Press.

ZOOMERS, A. (1999), Linking livelihood strategies to development. Experiences from the Bolivian Andes. Amsterdam: Royal Tropical Institute/Center for Research and Documentation on Latin America. 